\title{
Do associations of sex, age and education with transport and leisure-time physical activity differ across 17 cities in 12 countries?
}

Josef Mitáś ${ }^{1 *}$ (D) Ester Cerin ${ }^{2,3}$, Rodrigo Siqueira Reis ${ }^{4,5}$, Terry L. Conway ${ }^{6}$, Kelli L. Cain ${ }^{6}$, Marc A. Adams ${ }^{7}$, Grant Schofield ${ }^{8}$, Olga L. Sarmiento ${ }^{9}$, Lars B. Christiansen ${ }^{10}$, Rachel Davey ${ }^{11}$, Deborah Salvo ${ }^{4}$, Rosario Orzanco-Garralda ${ }^{12}$, Duncan Macfarlane ${ }^{13}$, Adriano Akira F. Hino ${ }^{14}$, Ilse De Bourdeaudhuij ${ }^{15}$, Neville Owen ${ }^{16,17}$, Delfien Van Dyck ${ }^{15,18}$ and James F. Sallis ${ }^{2,6}$

\begin{abstract}
Background: Leisure-time and transport activity domains are studied most often because they are considered more amenable to intervention, but to date evidence on these domains is limited. The aim of the present study was to examine patterns of socio-demographic correlates of adults' leisure-time and transport physical activity and how these associations varied across 17 cities in 12 countries.

Methods: Participants $(N=13,745)$ aged $18-66$ years in the IPEN Adult study and with complete data on sociodemographic and self-reported physical activity characteristics were included. Participants reported frequency and duration of leisure-time and transport activities in the last 7 days using the self-administered International Physical Activity Questionnaire-Long Form. Six physical activity outcomes were examined in relation with age, education, and sex, and analyses explored variations by city and curvilinear associations.
\end{abstract}

Results: Sex had the most consistent results, with five of six physical activity outcomes showing females were less active than males. Age had the most complex associations with self-report transport and leisure-time physical activity. Compared to older people, younger adults were less likely to engage in transport physical activity, but among those who did, younger people were likely to engage in more active minutes. Curvilinear associations were found between age and all three leisure-time physical activity outcomes, with the youngest and the oldest being more active. Positive associations with education were found for leisure-time physical activity only. There were significant interactions of city with sex and education for multiple physical activity outcomes.

Conclusions: Although socio-demographic correlates of physical activity are widely studied, the present results provide new information. City-specific findings suggest there will be value in conducting more detailed case studies. The curvilinear associations of age with leisure-time physical activity as well as significant interactions of leisure-time activity with sex and education should be further investigated. The findings of lower leisure-time physical activity among females as well as people with low education suggest that greater and continued efforts in physical activity policies and programs tailored to these high-risk groups are needed internationally.

Keywords: Social epidemiology, International health, Physical activity domain, IPAQ, Health disparities

\footnotetext{
*Correspondence: josef.mitas@upol.cz

'Institute of Active Lifestyle, Faculty of Physical Culture, Palacký University,

Olomouc, Czech Republic

Full list of author information is available at the end of the article
}

(c) The Author(s). 2019 Open Access This article is distributed under the terms of the Creative Commons Attribution 4.0 International License (http://creativecommons.org/licenses/by/4.0/), which permits unrestricted use, distribution, and reproduction in any medium, provided you give appropriate credit to the original author(s) and the source, provide a link to the Creative Commons license, and indicate if changes were made. The Creative Commons Public Domain Dedication waiver (http://creativecommons.org/publicdomain/zero/1.0/) applies to the data made available in this article, unless otherwise stated. 


\section{Background}

Increasing physical activity (PA) has been identified by the United Nations [1] and World Health Organization [2] as one of four key strategies for reducing global epidemics of non-communicable diseases (NCDs). NCDs and low levels of PA are common among countries of low, medium, and high incomes [3-9]. Worldwide, physical inactivity is more prevalent among females and linearly increases with ageing populations [10]. Understanding the correlates and determinants of PA provides evidence that can be used to guide the development of interventions and policies targeted to benefit higher-risk groups [11]. Relatively consistent correlates have been documented at individual (biological, psychological), social, and built environmental levels of influence [11]. Among the most widely studied correlates are sociodemographic variables of sex, age, and education [11, 12], and these variables can be used to identify subgroups at highest risk for inactivity.

Correlates often differ by the domain of PA; i.e., leisure-time, transport, occupation, and household [12, 13]. Leisure-time and transport activity domains are studied most often because they are considered more amenable to intervention. Psychological and built environment correlates and determinants differ substantially by these two domains [11], but less attention has been paid to differences in demographic correlates between these domains of PA. There has been little research examining variations in these associations across countries. Prior studies examined demographic correlates of overall PA [14], walking [15], and sitting [16], but to date evidence on domain-specific leisure-time and transport activity is limited to national studies or comparisons between populations from high-income countries.

The International Physical Activity and Environment Network (IPEN) Adult study was the first opportunity to examine relationships between demographic correlates and domain-specific activities of adults across diverse countries. IPEN was a multi-country cross-sectional epidemiologic study using a common design and comparable methods [17]. The data from both middle- and high-income countries allowed enhanced analyses of the domain-specific correlates of physical activity internationally. The aim of the present study was to examine patterns of socio-demographic correlates of adults' leisure-time and transport physical activity and how these associations varied across diverse countries.

\section{Methods}

\section{Study design}

IPEN participants were recruited from 17 cities across 12 countries: Australia (Adelaide, AU), Belgium (Ghent, $\mathrm{BE})$, Brazil (Curitiba, BR), Colombia (Bogota, CO), Czech Republic (Olomouc and Hradec Králové, CZ), Denmark
(Aarhus, DK), Hong Kong/China (HK), Mexico (Cuernavaca, MX), New Zealand (North Shore, Waitakere, Wellington, and Christchurch, NZ), Spain (Pamplona, ES), the United Kingdom (Stoke-on-Trent, UK), and the United States of America (Seattle/King County, Washington and Baltimore, Maryland region, US). The IPEN Adult study was designed to maximize variability in neighborhood environmental attributes related to walking and socioeconomic status (SES) by recruiting participants from neighborhoods stratified a priori for high/ low walkability and high/low SES [17].

Using objective geographical information systems (GIS) data, a walkability index [18] was used to stratify neighborhood areas, except in Spain where neighborhoods were stratified based on their construction date (a proxy measure of walkability). The smallest administrative or census unit that represented a neighborhoodlevel geographic sector was selected for the development of the walkability measures. Administrative units were ranked into deciles based on the normalized walkability index and on neighborhood-level SES data drawn from the census (e.g., household income, education attainment, or an index) in each city. The walkability index and census-based SES scores were crossed to produce four neighborhood quadrants: high walkable / high SES; high walkable / low SES; low walkable / high SES; and low walkable / low SES. The details for each country can be found elsewhere [17].

\section{Participant recruitment}

Households in the selected neighborhoods were identified using databases from commercial and government sources in most cities. In each selected household, an adult was invited to complete a survey and wear an accelerometer, with study dates ranging from 2002 to 2011. More information on participant recruitment can be found elsewhere [17]. Each country obtained ethical approval from their local institutional review boards, and all participants provided informed consent.

\section{Participants}

The entire IPEN Adult study consisted of 14,222 adults aged 18-66 years. The current study examined data from 13,745 participants from 17 study cities across 12 countries with complete data on socio-demographic and selfreported PA characteristics.

\section{Measures \\ Socio-demographic characteristics}

Self-reported socio-demographic variables included age, sex, education, working status, and marital status. Years of education were categorized into 'less than high school', 'high school graduate' and 'college degree or more'. Working status was recoded as working or not, 
and marital status was dichotomized into living as a couple versus not.

\section{Physical activity}

This study employed the self-administered International Physical Activity Questionnaire-Long Form (IPAQ-LF), which was a validated measure designed for international use $[14,19]$. The IPAQ-LF collected data on reported frequency and duration (bouts of at least $10 \mathrm{~min}$ ) of moderate and vigorous activities for each domain (occupation, transport, household, and leisure-time) over the last seven days. For present analyses, only summary scores for leisure-time and transport activity were used because not all countries collected data on occupation and household PA. Three outcomes for each domain were calculated to reflect some of the complexity of PA patterns. First, engaging $\geq 10 \mathrm{~min} /$ week in the PA domain with a binary outcome (no vs. yes) identified people who reported any PA in the domain. Second, duration of PA in the domain (only including respondents with nonzero minutes of PA) provided a continuous measure of PA in each domain. Third, engaging in $\geq 150 \mathrm{~min} /$ week of PA in the domain was a binary outcome that identified participants who engaged in a substantial amount of PA, sufficient to achieve the recommended weekly amount in a single domain of PA.

\section{Data analytic plan}

Descriptive statistics (relative frequencies, means, standard deviations and percentages of missing values) were computed for all variables for the whole sample and by city. Associations of age, educational attainment and sex with PA outcomes, and the moderating effects of city, were estimated using generalized additive mixed models (GAMMs) [20]; accounting for clustering effects at the administrative unit level [21]. GAMMs with binomial variance and logit link functions were used for the binary outcomes (e.g., not engaging vs. engaging in $\geq 150$ min/week of leisure-time PA), while GAMMs with Gamma variance and logarithmic link functions were used for the two continuous PA outcomes (to account for the fact that the outcome could only assume positive values and residuals were positively skewed). Each measure of weekly minutes of PA was operationalized as a binary (engagement in $\geq 10 \mathrm{~min} /$ week of PA) and a continuous variable (non-zero $\mathrm{min} /$ week of $\mathrm{PA}$ ) because preliminary analyses indicated that the number of zero values was significantly greater than that expected under a Gamma distribution. The reported exponential function of the regression coefficients of the GAMMs for binary outcomes represent odds ratios, while those of the GAMMs for continuous outcomes represent the proportional increase in non-zero weekly minutes of PA associated with 1 unit increase in the predictor.
Main-effect GAMMs estimated the relationships of age, sex, and educational attainment with the PA outcomes, adjusting for city, other socio-demographic factors (employment and marital status), and the design variables, administrative-unit-level socio-economic status and walkability. Fully-adjusted (all variables entered) GAMMs were estimated. For all main effects, a twotailed probability level of 0.05 was adopted. Curvilinear associations of age with PA outcomes were estimated using non-parametric thin-plate splines in GAMMs [20]. Smooth terms failing to provide sufficient evidence of a curvilinear relationship (based on a 10-unit difference in Akaike Information Criterion; AIC) were replaced by simpler linear terms [20]. Separate GAMMs were run to estimate city by socio-demographic factor (age, educational attainment, and sex) interaction effects. This was done by adding two-way interaction terms to the main effect models. In the presence of curvilinear relationships (e.g., when examining the moderating effects of city on age-PA relationships), the significance of an interaction effect was evaluated by comparing AIC values of models with and without a specific interaction term(s). In such case, an interaction effect was deemed significant if it yielded an AIC 10 or more units smaller than the main effect model, indicating no support for the simpler model [22]. For city by categorical sociodemographic factor interaction effects and in the presence of a linear relationship between age and a PA variable, the significance of the specific interaction effect was determined using F-tests comparing the fit of the models with and without the interaction terms. A twotailed significance level of 0.05 was adopted for these analyses. Significant interaction effects were probed by computing city-specific associations using linear combinations of regression coefficients based on the pooled data. Given that fewer than $5 \%$ of cases $(3.72 \% ; n=512)$ had missing data, data analyses were performed on complete cases [22]. All analyses were conducted in $\mathrm{R}$ version 3.2.1 [23] using the packages 'car' version 2.0.26 [24], 'mgcv' version 1.8.7, and 'gamm4' version 0.2.3 [20], and 'gmodels' version 2.16.2 [25].

\section{Results}

Among the 13,745 participants, the average age was 42 years old, and nearly half were males $(43 \%)$ and had a college degree or higher (44\%). The majority of the pooled sample reported working (74\%), living with a partner $(59 \%)$, and participating in any transport (76\%) or leisure-time PA (71\%). Study site was associated with transport and leisure-time PA. Overall, $41 \%$ of participants accumulated $\geq 150 \mathrm{~min} /$ week of transport PA, ranging from $16 \%$ in Waitakere (NZ) to $65 \%$ in Aarhus. Overall, $45 \%$ of participants accumulated $\geq 150 \mathrm{~min} /$ week of leisure-time PA, ranging from $29 \%$ in 
Cuernavaca (MX) to $72 \%$ in Aarhus (DK). All descriptive characteristics by cities are shown in Table 1 .

\section{Associations of age, educational attainment, and sex with physical activity - main effects}

Age was significantly but complexly associated with all PA outcomes $(p<0.01)$ (Table 2; Figs. 1 and 2), with the exception of a non-significant association for engaging in $\geq 150 \mathrm{~min} /$ week of transport PA. A linear negative association was observed with the odds of engaging in $\geq 10$ $\mathrm{min} /$ week of transport PA $(\mathrm{OR}=0.991 ; 95 \% \mathrm{CI}$ : 0.987, 0.994; see Table 2), but a positive association was found with non-zero weekly minutes of transport PA in those adults $(n=10,166)$ who reported engaging in this domain of PA.

In contrast to transport PA, age was non-linearly related to the odds of engaging in $\geq 10 \mathrm{~min} /$ week of leisure-time PA (Fig. 1 panels A). An inverted-U relationship was observed between age and non-zero weekly minutes of leisure-time PA in those who reported

Table 1 Overall and site-specific sample characteristics: socio-demographics and physical activity (PA) outcomes

\begin{tabular}{|c|c|c|c|c|c|c|c|c|c|c|c|c|c|c|c|c|c|c|}
\hline \multirow{2}{*}{ 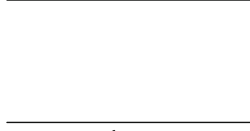 } & \multirow{2}{*}{$\begin{array}{l}\text { ALL } \\
\text { SITES }\end{array}$} & \multirow[t]{2}{*}{$\mathrm{AU}$} & \multirow[t]{2}{*}{$\mathrm{BE}$} & \multirow[t]{2}{*}{$\mathrm{BR}$} & \multirow[t]{2}{*}{$\mathrm{CO}$} & \multicolumn{2}{|l|}{$C Z$} & \multirow[t]{2}{*}{ DK } & \multirow[t]{2}{*}{ HK } & \multirow[t]{2}{*}{ MX } & \multicolumn{4}{|l|}{$\mathrm{NZ}$} & \multirow[t]{2}{*}{ ES } & \multirow[t]{2}{*}{ UK } & \multicolumn{2}{|l|}{ US } \\
\hline & & & & & & $\begin{array}{l}\text { City } \\
\text { A }\end{array}$ & $\begin{array}{l}\text { City } \\
\text { B }\end{array}$ & & & & $\begin{array}{l}\text { City } \\
\text { C }\end{array}$ & $\begin{array}{l}\text { City } \\
\text { D }\end{array}$ & $\begin{array}{l}\text { City } \\
\text { E }\end{array}$ & $\begin{array}{l}\text { City } \\
\text { F }\end{array}$ & & & $\begin{array}{l}\text { City } \\
\text { G }\end{array}$ & $\begin{array}{l}\text { City } \\
\mathrm{H}\end{array}$ \\
\hline Overall $N^{1}$ & $\begin{array}{l}13 \\
745\end{array}$ & 2650 & 1166 & 697 & 963 & 330 & 167 & 642 & 495 & 677 & 511 & 512 & 496 & 495 & 904 & 843 & 1287 & 912 \\
\hline $\begin{array}{l}\text { Mean age (SD) } \\
\text { missing: } 1.5 \%\end{array}$ & $\begin{array}{l}42 \\
(12.8)\end{array}$ & $\begin{array}{l}44 \\
(12.3)\end{array}$ & $\begin{array}{l}43 \\
(12.6)\end{array}$ & $\begin{array}{l}41 \\
(13.2)\end{array}$ & $\begin{array}{l}40 \\
(13.7)\end{array}$ & $\begin{array}{l}38 \\
(14.7)\end{array}$ & $\begin{array}{l}34 \\
(13.1)\end{array}$ & $\begin{array}{l}39 \\
(13.9)\end{array}$ & $\begin{array}{l}43 \\
(11.7)\end{array}$ & $\begin{array}{l}42 \\
(12.6)\end{array}$ & $\begin{array}{l}41 \\
(11.8)\end{array}$ & $\begin{array}{l}41 \\
(11.8)\end{array}$ & $\begin{array}{l}39 \\
(12.6)\end{array}$ & $\begin{array}{l}42 \\
(12.6)\end{array}$ & $\begin{array}{l}39 \\
(14.2)\end{array}$ & $\begin{array}{l}43 \\
(13.3)\end{array}$ & $\begin{array}{l}44 \\
(11.0)\end{array}$ & $\begin{array}{l}47 \\
(10.7)\end{array}$ \\
\hline $\begin{array}{l}\text { Sex, } \% \text { men } \\
\text { missing: } 0.3 \%\end{array}$ & 43 & 36 & 48 & 47 & 36 & 37 & 40 & 43 & 41 & 45 & 36 & 39 & 49 & 44 & 45 & 44 & 55 & 48 \\
\hline \multicolumn{19}{|l|}{$\begin{array}{l}\text { Education, } \% \\
\text { missing: } 1.2 \%\end{array}$} \\
\hline Less than HS & 17 & 24 & 4 & 29 & 36 & 22 & 17 & 8 & 37 & 43 & 4 & 5 & 1 & 11 & 7 & 34 & 1 & 2 \\
\hline HS graduate & 38 & 30 & 35 & 32 & 42 & 46 & 57 & 44 & 23 & 29 & 58 & 64 & 47 & 57 & 35 & 52 & 36 & 30 \\
\hline College or more & 44 & 46 & 61 & 39 & 22 & 32 & 26 & 48 & 40 & 28 & 38 & 31 & 52 & 32 & 58 & 14 & 63 & 68 \\
\hline $\begin{array}{l}\text { Work status, } \% \\
\text { working missing: } \\
0.3 \%\end{array}$ & 74 & 71 & 80 & 78 & 58 & 77 & 84 & 75 & 66 & 72 & 78 & 84 & 87 & 80 & 72 & 64 & 81 & 83 \\
\hline $\begin{array}{l}\text { Marital status, } \\
\text { \%couple missing: } \\
1.2 \%\end{array}$ & 59 & 57 & 73 & 58 & 53 & 58 & 47 & 65 & 58 & 65 & 70 & 74 & 57 & 55 & 53 & 45 & 63 & 60 \\
\hline $\begin{array}{l}\text { Any }>10 \mathrm{~min} / \text { week } \\
\text { transport-related PA, } \\
\% \text { missing: } 0.4 \%\end{array}$ & 76 & 76 & 72 & 79 & 91 & 84 & 87 & 86 & 79 & 90 & 66 & 64 & 86 & 61 & 89 & 65 & 69 & 68 \\
\hline $\begin{array}{l}\text { Any }>10 \text { min/week } \\
\text { leisure-time PA, } \% \\
\text { missing: } 0.5 \%\end{array}$ & 71 & 70 & 74 & 55 & 55 & 76 & 78 & 90 & 68 & 52 & 71 & 74 & 84 & 67 & 86 & 57 & 80 & 73 \\
\hline $\begin{array}{l}\text { Non-zero mean min/ } \\
\text { week transport- } \\
\text { related } \mathrm{PA}^{2} \text { (SD) } \\
\mathrm{n}=10,510\end{array}$ & $\begin{array}{l}283 \\
(365)\end{array}$ & $\begin{array}{l}273 \\
(358)\end{array}$ & $\begin{array}{l}199 \\
(211)\end{array}$ & $\begin{array}{l}207 \\
(304)\end{array}$ & $\begin{array}{l}338 \\
(424)\end{array}$ & $\begin{array}{l}486 \\
(499)\end{array}$ & $\begin{array}{l}424 \\
(457)\end{array}$ & $\begin{array}{l}364 \\
(407)\end{array}$ & $\begin{array}{l}308 \\
(328)\end{array}$ & $\begin{array}{l}336 \\
(485)\end{array}$ & $\begin{array}{l}144 \\
(204)\end{array}$ & $\begin{array}{l}148 \\
(251)\end{array}$ & $\begin{array}{l}229 \\
(256)\end{array}$ & $\begin{array}{l}172 \\
(227)\end{array}$ & $\begin{array}{l}369 \\
(363)\end{array}$ & $\begin{array}{l}333 \\
(423)\end{array}$ & $\begin{array}{l}266 \\
(374)\end{array}$ & $\begin{array}{l}259 \\
(315)\end{array}$ \\
\hline $\begin{array}{l}\text { Non-zero mean min/ } \\
\text { week leisure-time } \\
\text { PA }^{2} \\
n=9734\end{array}$ & $\begin{array}{l}312 \\
(322)\end{array}$ & $\begin{array}{l}294 \\
(313)\end{array}$ & $\begin{array}{l}239 \\
(250)\end{array}$ & $\begin{array}{l}245 \\
(257)\end{array}$ & $\begin{array}{l}301 \\
(333)\end{array}$ & $\begin{array}{l}428 \\
(356)\end{array}$ & $\begin{array}{l}473 \\
(421)\end{array}$ & $\begin{array}{l}462 \\
(408)\end{array}$ & $\begin{array}{l}267 \\
(290)\end{array}$ & $\begin{array}{l}277 \\
(276)\end{array}$ & $\begin{array}{l}240 \\
(249)\end{array}$ & $\begin{array}{l}221 \\
(233)\end{array}$ & $\begin{array}{l}322 \\
(305)\end{array}$ & $\begin{array}{l}249 \\
(221)\end{array}$ & $\begin{array}{l}437 \\
(398)\end{array}$ & $\begin{array}{l}348 \\
(351)\end{array}$ & $\begin{array}{l}307 \\
(301)\end{array}$ & $\begin{array}{l}295 \\
(307)\end{array}$ \\
\hline $\begin{array}{l}\text { Transport-related PA, } \\
\% \text { accumulating } \geq \\
150 \text { min/week } \\
\text { missing: } 0.4 \%\end{array}$ & 41 & 39 & 35 & 30 & 54 & 65 & 60 & 59 & 51 & 45 & 21 & 16 & 45 & 22 & 63 & 35 & 35 & 35 \\
\hline $\begin{array}{l}\text { Leisure-time PA, } \% \\
\text { accumulating } \geq 150 \\
\text { min/week } \\
\text { missing: } 0.5 \%\end{array}$ & 45 & 43 & 42 & 32 & 32 & 59 & 59 & 72 & 38 & 29 & 40 & 38 & 56 & 41 & 66 & 38 & 52 & 45 \\
\hline
\end{tabular}


Table 2 Associations of age, educational attainment and sex with physical activity (PA) outcomes: Main effects for entire sample

\begin{tabular}{|c|c|c|c|c|c|}
\hline \multirow[t]{3}{*}{ PA outcome } & \multirow[t]{3}{*}{$\mathrm{n}$} & \multirow{3}{*}{$\begin{array}{l}\text { Age } \\
e^{b}\left(e^{95 \% c l}\right)\end{array}$} & \multicolumn{2}{|c|}{$\begin{array}{l}\text { Educational attainment } \\
\text { (reference: < high school graduate) }\end{array}$} & \multirow{3}{*}{$\begin{array}{l}\text { Sex } \\
\text { (reference: male) } \\
\text { Female }\end{array}$} \\
\hline & & & $\begin{array}{l}\text { High school graduate or some } \\
\text { college }\end{array}$ & $\begin{array}{l}\text { College degree or } \\
\text { higher }\end{array}$ & \\
\hline & & & $e^{b}\left(e^{95 \% C l}\right)$ & $e^{b}\left(e^{95 \% C l}\right)$ & \\
\hline \multicolumn{6}{|c|}{ Transport-related PA (no significant curvilinear associations) } \\
\hline Yes, $\geq 10 \mathrm{~min} /$ week $^{\mathrm{a}}$ & 13,233 & & $F(2,13.208)=7.42^{* * *}$ & & \\
\hline linear: & & $0.991(0.987,0.994)^{* * *}$ & $0.95(0.83,1.09)$ & $1.15(1.00,1.33)$ & $1.02(0.94,1.11)$ \\
\hline Non-zero min/week ${ }^{b}$ & 10,166 & & $F(2,10,141)=9.24^{* * *}$ & & \\
\hline linear: & & $1.003(1.001,1.004)^{* *}$ & $1.00(0.94,1.06)$ & $0.89(0.84,0.95)^{* *}$ & $0.87(0.84,0.91)^{* * *}$ \\
\hline $\mathrm{Yes}, \geq 150 \mathrm{~min} /$ week $^{\mathrm{a}}$ & 13,233 & & $F(2,13,208)=0.23$ & & \\
\hline linear: & & $1.001(0.998,1.004)$ & $1.04(0.93,1.17)$ & $1.02(0.91,1.16)$ & $0.90(0.84,0.98)^{* *}$ \\
\hline \multicolumn{6}{|l|}{ Leisure-time PA } \\
\hline Yes, $\geq 10 \mathrm{~min} /$ week $^{\mathrm{a}}$ & 13,233 & & $F(2,13,209)=146.32^{* * *}$ & & \\
\hline linear: & & $0.750(0.549,1.025)$ & $1.51(1.35,1.70)^{* * *}$ & $2.16(1.90,2.45)^{* * *}$ & $0.90(0.83,0.97)^{* *}$ \\
\hline $\begin{array}{l}\text { curvilinear (smooth term) } \\
c_{:}\end{array}$ & & $\begin{array}{l}X^{2}(3.94)=46.96^{* * *} \\
\text { (see Fig. 1a) }\end{array}$ & - & - & - \\
\hline Non-zero min/week ${ }^{b}$ & 9427 & & $F(2,9403)=3.84^{*}$ & & \\
\hline linear: & & $1.025(0.854,1.231)$ & $1.02(0.96,1.09)$ & $0.95(0.89,1.02)$ & $0.87(0.84,0.91)^{* * *}$ \\
\hline $\begin{array}{l}\text { curvilinear (smooth term) } \\
\text { c: }\end{array}$ & & $\begin{array}{l}F(3.68,9399.30)=5.42^{* * *} \\
\text { (see Fig. 1b) }\end{array}$ & - & - & - \\
\hline Yes, $\geq 150 \mathrm{~min} /$ week $^{\mathrm{a}}$ & 13,233 & & $F(2,13,209)=81.11^{* * *}$ & & \\
\hline linear: & & $0.889(0.697,1.134)$ & $1.43(1.27,1.61)^{* * *}$ & $1.75(1.55,1.98)^{* * *}$ & $0.87(0.81,0.94)^{* * *}$ \\
\hline $\begin{array}{l}\text { curvilinear (smooth term) } \\
\text { c. }\end{array}$ & & $\begin{array}{l}X^{2}(3.53)=18.56^{* * *} \\
\text { (see Fig. 2) }\end{array}$ & - & - & - \\
\hline
\end{tabular}

$95 \% \mathrm{Cl}=95 \%$ confidence interval; exp.(b) exponential function of regression coefficient; exp. $95 \% \mathrm{Cl}$ )= exponential function of confidence interval; $\mathrm{n}=$ sample size ${ }^{a}$ Generalized additive mixed model (GAMM) with binomial variance and logit link functions, for which exp.(b) is interpreted as odds ratio

${ }^{\mathrm{b}}$ GAMM with Gamma variance and logarithmic link functions, for which exp.(b) is interpreted as the proportional increase in PA associated with a 1 unit increase in the predictor

c The approximate statistical significance of the smooth term is based on chi-squared $\left(x^{2}\right)$ and F-ratio statistic for GAMMs with binomial and Gamma variance function, respectively. All models adjusted for city, working status, marital status, administrative-unit-level socio-economic status and walkability

${ }^{*} p$-value ranging from $\leq .05$ to $>.01 ;{ }^{* *} p$-value ranging from $\leq 01$ to $>.001 ;{ }^{* * *} p \leq .001$

engaging in this type of activity $(n=9427)$, with the average amount of leisure-time PA decreasing from $~ 320$ to $\sim 280 \mathrm{~min} /$ week from 18 to 35 years of age and then steadily increasing (Fig. 1; panel B). The dose-response relationship between age and the odds of engaging in $\geq 150 \mathrm{~min} /$ week of leisure-time PA was similar in shape to that for the odds of engaging in $\geq 10 \mathrm{~min} /$ week of leisure-time PA (Fig. 2).

Those with a college degree were significantly more likely to engage in any transport PA than those who completed high school or had some college education $(\mathrm{OR}=1.214 ; 95 \% \mathrm{CI}: 1.099,1.342 ; p<0.001)$. In contrast, educational attainment was negatively related to nonzero weekly minutes of transport PA. Specifically, those with a college degree reported $11 \%$ (95\% CI: 5, 16\%) fewer minutes than those with less education (Table 2). Overall, educational attainment was positively related to the odds of engaging in $\geq 10$ and $\geq 150 \mathrm{~min} /$ week of leisure-time PA (Table 2). However, among participants who engaged in leisure-time PA, those with high school education tended to accumulate more non-zero weekly minutes of leisure-time PA than those with a college or higher degree $\left(\mathrm{e}^{\mathrm{b}}=1.067 ; \mathrm{e}^{95 \% \mathrm{CI}}: 1.019,1.117 ; p=0.005\right)$.

Sex showed a significant association with all PA outcomes with the exception of $\geq 10 \mathrm{~min} /$ week of transport PA (Table 2). For both domains, females were less likely to engage in PA and reported fewer non-zero minutes of activity compared to males.

\section{Moderating effects of city on associations of age, educational attainment, and sex with physical activity outcomes}

City moderated associations of age with four out of six PA outcomes (Table 3). Specifically, age was significantly negatively related to the odds of engaging in $\geq 10 \mathrm{~min} /$ week of transport PA in nine cities and positively related in three cities, while no significant associations were found in the remaining five cities (Table 3). Age was positively related to non-zero weekly minutes of transport PA (in those who reported at least $10 \mathrm{~min}$ of this 

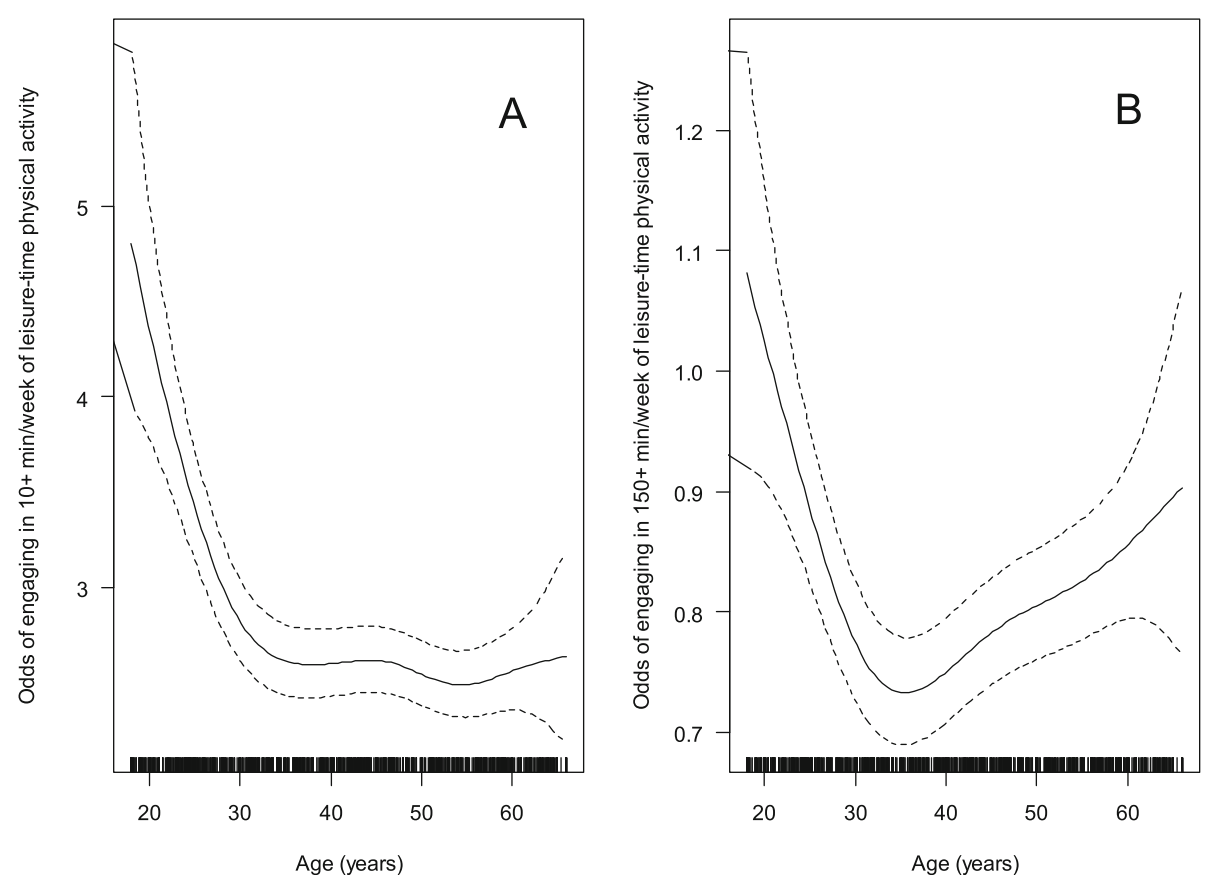

Fig. 1 Relationships of age with the odds of engaging in $\geq 10$ (panel A) and $\geq 150$ (panel B) weekly minutes of leisure-time physical activity

type of PA) in Ghent (BE), Olomouc (CZ), Aarhus (DK) and Pamplona (ES), and age was non-significantly related in other cities. Age was significantly negatively related to the odds of engaging in $\geq 150 \mathrm{~min} /$ week of transport PA only in Wellington (NZ) and positively related in Hong Kong and Pamplona (ES). Negative associations of age with the odds of engaging in $\geq 10 \mathrm{~min} /$ week of leisure-time PA were found in eight cities, while only Pamplona (ES) showed a weak positive association (Table 3).

City moderated associations of educational attainment and non-zero minutes of leisure-time PA only (Table 4). Negative associations were found in Aarhus (DK), Hong Kong, and Pamplona (ES), while positive associations were observed in Bogota (CO), Cuernavaca (MX), and Waitakere (NZ) (Table 4).

City moderated associations of sex with three PA outcomes; engagement in $\geq 10 \mathrm{~min} /$ week of leisure-time PA and non-zero weekly minutes of transport and leisuretime PA (Table 5). Females were more likely than males to engage in $\geq 10 \mathrm{~min} /$ week of leisure-time PA in Ghent (BE) and Aarhus (DK), and females were less likely to do so in Adelaide (AU) and Bogota (CO). On average, compared to males, females accumulated fewer non-zero weekly minutes of leisure-time PA in four out of 17 cities and fewer non-zero weekly minutes of transport PA in five cities (Table 5).

\section{Discussion}

These detailed international analyses present a more complex pattern of socio-demographic associations with
PA for transport and leisure purposes than is apparent in the large literature on this topic that was mainly from single countries [26-29]. Table 6 provides a simplified summary of the main effects and demographic-by-city interactions across outcomes, to assist in interpretation. In the IPEN Adult study age had the most complex associations with self-report transport and leisure-time PA. Older people in the sample were less likely to report any use of transport PA, but they reported more total minutes if they used transport PA. Perhaps this pattern reflects that older people were more likely to have cars, but those who did not have cars were more dependent on walking and bicycling. Studies of transport PA by age are rare, so the present results add new information that needs to be replicated.

Negative associations of age with leisure-time or total PA are among the most consistent correlates in studies of adults $[11,12]$. Thus, it was surprising that the only simple negative linear main effect was for the odds of engaging in $\geq 10 \mathrm{~min} /$ week of transport PA. Unlike prior studies, we evaluated non-linear associations and found all three age associations with leisure-time PA measures were significantly non-linear. Present results also differed from previous global status report analyses [10]. Thus, we encourage other investigators to explore nonlinear associations in their data. A possible environmental explanation is that different age groups prioritize different factors in selecting places to live, perhaps with younger adults choosing neighborhoods in suburban areas perceived as safer for children but that have fewer 

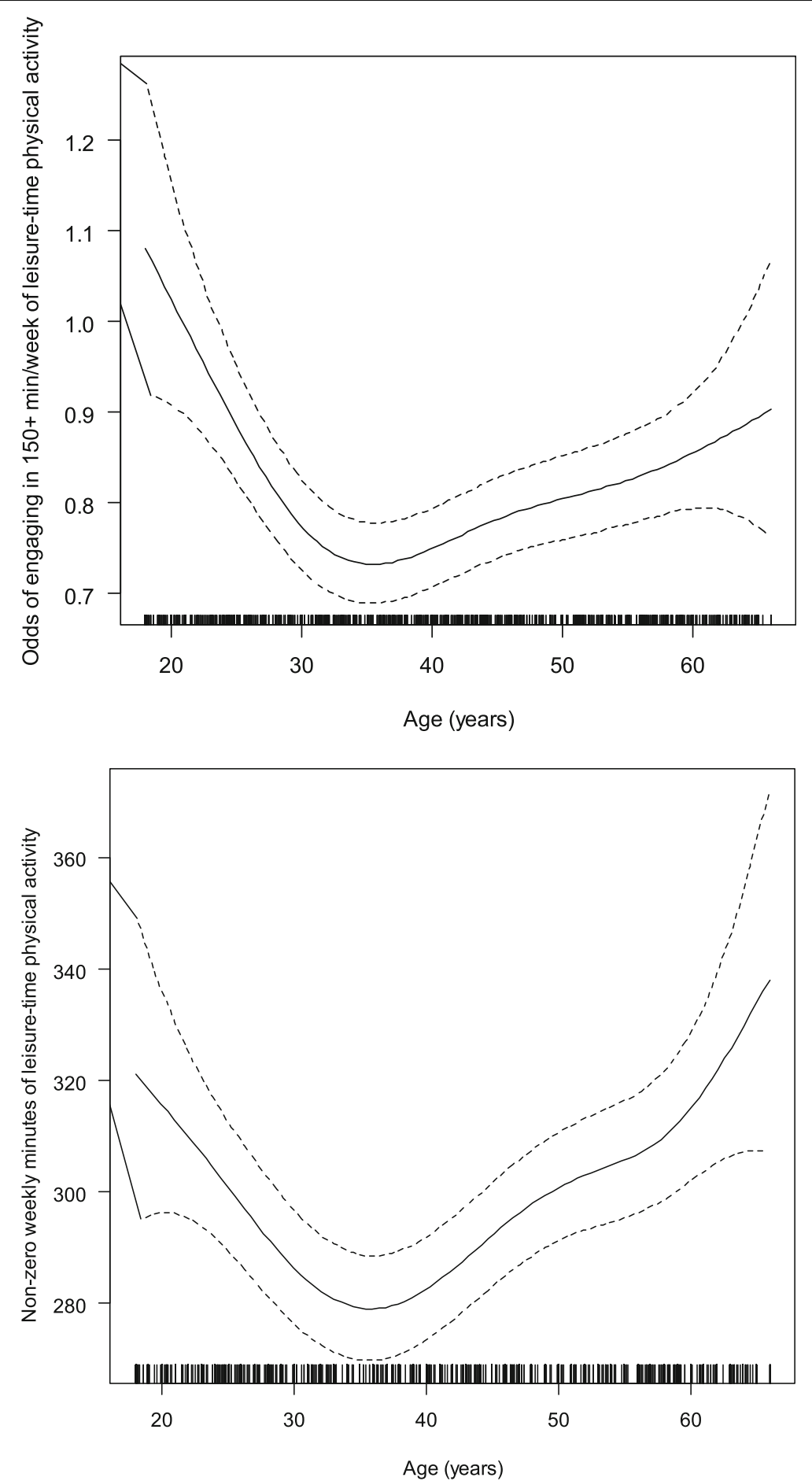

Fig. 2 Relationship of age with the odds of engaging in $\geq 150$ weekly minutes of leisure-time physical activity

recreational facilities for adults. Older adults may prefer more walkable neighborhoods where they can access recreation and community centers where they could socialize with neighbors more easily [30]. Life stage may also explain the curvilinear associations with younger adults reducing leisure time activities to spend more time building their careers and raising children. As children leave home and careers are more stable, perhaps middleaged people are able to spend more time in leisure PA.

Interactions of age and city were significant for three transport and one leisure-time PA outcomes. For $\geq 10$ min/week of both transport and leisure-time PA, over 
Table 3 City-specific associations of age with physical activity (PA) outcomes

\begin{tabular}{|c|c|c|c|c|}
\hline \multirow[t]{2}{*}{ City } & $\geq 10 \mathrm{~min} /$ week of transport $\mathrm{PA}^{\mathrm{a}}$ & Non-zero min/week of transport PA ${ }^{\mathrm{b}}$ & $\geq 150 \mathrm{~min} /$ week of transport $\mathrm{PA}^{\mathrm{a}}$ & $\geq 10 \mathrm{~min} /$ week of leisure-time $\mathrm{PA}^{\mathrm{a}}$ \\
\hline & $\begin{array}{l}F(17,13,192)=3.27^{* * *} \\
e^{b}\left(e^{95 \% C_{1}}\right)\end{array}$ & $\begin{array}{l}F(17,10,125)=12.99^{* * *} \\
e^{b}\left(e^{95 \% c l}\right)\end{array}$ & $\begin{array}{l}F(17,13,192)=3.41^{* * *} \\
e^{b}\left(e^{95 \% c l}\right)\end{array}$ & $\begin{array}{l}F(17,13,192)=70.78^{* * *} \\
e^{b}\left(e^{95 \%(c)}\right)\end{array}$ \\
\hline Adelaide (AU) & $0.991(0.986,0.996)^{* * *}$ & $1.001(0.997,1.004)$ & $1.000(0.993,1.006)$ & $0.995(0.987,1.002)$ \\
\hline Ghent (BE) & $0.985(0.980,0.991)^{* * *}$ & $1.007(1.002,1.012)^{*}$ & $1.003(0.993,1.013)$ & $0.996(0.986,1.007)$ \\
\hline Curitiba (BR) & $0.993(0.987,1.000)^{*}$ & $0.996(0.990,1.003)$ & $1.004(0.991,1.016)$ & $1.000(0.988,1.011)$ \\
\hline Bogota (CO) & $1.014(1.007,1.022)^{* * *}$ & $1.000(0.995,1.004)$ & $1.003(0.994,1.013)$ & $0.985(0.975,0.994)^{* *}$ \\
\hline Olomouc (CZ) & $0.998(0.988,1.007)$ & $1.018(1.009,1.027)^{* * *}$ & $0.995(0.978,1.013)$ & $0.971(0.951,0.990)^{* * *}$ \\
\hline Hradec Králové (CZ) & $1.009(0.994,1.025)$ & $1.007(0.995,1.019)$ & $1.008(0.983,1.034)$ & $0.965(0.938,0.994)^{*}$ \\
\hline Aarhus (DK) & $1.001(0.993,1.010)$ & $1.013(1.007,1.020)^{* * *}$ & $0.998(0.985,1.010)$ & $0.968(0.949,0.989)^{* *}$ \\
\hline Hong Kong (HK) & $0.997(0.989,1.005)$ & $1.004(0.994,1.014)$ & $1.024(1.006,1.043)^{* *}$ & $1.009(0.989,1.029)$ \\
\hline Cuernavaca (MX) & $1.011(1.003,1.019)^{* *}$ & $0.997(0.991,1.003)$ & $1.002(0.990,1.014)$ & $0.979(0.966,0.991)^{* * *}$ \\
\hline North Shore (NZ) & $0.979(0.972,0.987)^{* * *}$ & $0.992(0.983,1.001)$ & $0.992(0.973,1.010)$ & $1.000(0.983,1.018)$ \\
\hline Waitakere (NZ) & $0.979(0.971,0.986)^{* * *}$ & $1.003(0.994,1.011)$ & $0.982(0.962,1.002)$ & $0.991(0.974,1.008)$ \\
\hline Wellington (NZ) & $1.001(0.992,1.010)$ & $0.997(0.990,1.005)$ & $0.973(0.958,0.989)^{* *}$ & $0.980(0.961,0.999)^{*}$ \\
\hline Christchurch (NZ) & $0.975(0.968,0.982)^{* * *}$ & $0.997(0.988,1.006)$ & $0.989(0.971,1.006)$ & 1.006 (0.990. 1.021) \\
\hline Pamplona (ES) & $1.010(1.002,1.017)^{*}$ & $1.010(1.006,1.015)^{* * *}$ & $1.027(1.016,1.037)^{* * *}$ & $1.016(1.002,1.029)^{*}$ \\
\hline Stoke-on-Trent (UK) & $0.983(0.977,0.989)^{* * *}$ & $0.997(0.991,1.003)$ & $0.995(0.984,1.006)$ & $0.995(0.984,1.006)$ \\
\hline Seattle (US) & $0.982(0.977,0.988)^{* * *}$ & $1.003(0.997,1.009)$ & $1.001(0.990,1.012)$ & $0.985(0.972,0.997)^{*}$ \\
\hline Baltimore (US) & $0.984(0.978,0.990)^{* * *}$ & $1.002(0.995,1.008)$ & $0.997(0.984,1.010)$ & $0.979(0.965,0.993)^{* *}$ \\
\hline
\end{tabular}

$95 \% \mathrm{Cl}=95 \%$ confidence interval; exp.(b) exponential function of regression coefficient; exp.(95\% Cl)=exponential function of confidence interval

${ }^{a}$ Generalized additive mixed model (GAMM) with binomial variance and logit link functions, for which exp.(b) is interpreted as odds ratio

${ }^{b}$ GAMM with Gamma variance and logarithmic link functions, for which exp.(b) is interpreted as the proportional increase in PA associated with a 1 unit

increase in the predictor. All models adjusted for working status, marital status, administrative-unit-level socio-economic status and walkability

${ }^{*} p$-value ranging from $\leq .05$ to $>.01 ;{ }^{* *} p$-value ranging from $\leq 01$ to $>.001 ;{ }^{* * *} p \leq .001$

half of cities had negative associations, and only three cities (Bogota, Cuernavaca and Pamplona) had positive associations. For non-zero minutes of transport PA, four cities had significant positive associations, with no negative associations. Though some of these divergent findings across cities could be due to modest sample sizes, it would be valuable for future studies to attempt to both confirm and explain city-specific age trends in transport and leisure-time PA related to social and built environment attributes. For instance, in Latin America a positive association between access public transit and minutes of transport physical activity have been reported among adults [31]. This association is reported in cities with low levels of car ownership and where walking to and from public transit access points is frequent.

Education had the fewest associations with PA in the present study, almost exclusively main effects of positive associations with categorical (no or yes) leisure-time PA. When comparing the college/university educated to those with less than high school, three European cities had negative associations and three cities had positive associations. Only nonzero minutes of transport activity had a negative main effect association for college educated adults, possibly because they could afford to live closer to destinations or transit. The general lack of association of education with transport PA was somewhat surprising. Although educational attainment is not an ideal proxy for income or overall SES, many studies show greater use of active travel modes by people with lower education [30, 32-35]. This pattern does not appear to generalize across countries. Transport PA may be concentrated among less-educated groups in countries with high automobile dependence, lower-quality public transport systems, and high income inequality. Perhaps income is a poorer proxy for SES in some countries where, for example, there are fewer high-paying jobs for well-educated people or where less-educated people often succeed in business. Socioeconomic inequalities are directly related to transport and leisure-time PA [26, 36], so present results might have been different if household income data had been available for inclusion. More international studies on the relation of SES to transport PA are needed.

Present results reinforce the consistent findings that education is positively related to leisure-time PA [11, 12]. These results suggest generalizability of this pattern because there was little evidence of differences by city. Only the continuous measure of non-zero minutes of leisure-time activity had a significant interaction with city, but there were few cities with significant associations, and these showed inconsistent directions. Better-educated adults are likely to have more discretionary time for leisure-time PA, more available resources such as health clubs and exercise classes, and less-active jobs that motivate them to seek leisure-time PA. 
Table 4 City-specific associations of educational attainment with non-zero weekly minutes of leisure-time physical activity

\begin{tabular}{|c|c|c|}
\hline \multirow[t]{3}{*}{ City } & \multicolumn{2}{|l|}{$\begin{array}{l}\text { Educational attainment } \\
\text { (reference: < high school graduate) }\end{array}$} \\
\hline & \multicolumn{2}{|l|}{$F(34,9368)=2.35^{* * *}$} \\
\hline & $\begin{array}{l}\text { High school graduate or some college } \\
e^{b}\left(e^{95 \% c l}\right)\end{array}$ & $\begin{array}{l}\text { College degree or higher } \\
e^{b}\left(e^{95 \% c l}\right)\end{array}$ \\
\hline Adelaide (AU) & $1.09(0.95,1.25)$ & $1.02(0.90,1.16)$ \\
\hline Ghent (BE) & $1.05(0.74,1.49)$ & $0.96(0.68,1.35)$ \\
\hline Curitiba (BR) & $1.10(0.84,1.44)$ & $1.01(0.78,1.31)$ \\
\hline Bogota (CO) & $0.99(0.81,1.22)$ & $1.44(1.13,1.81)^{* *}$ \\
\hline Olomouc (CZ) & $0.80(0.57,1.14)$ & $0.74(0.51,1.08)$ \\
\hline Hradec Králové (CZ) & $0.98(0.56,1.71)$ & $1.13(0.61,2.06)$ \\
\hline Aarhus (DK) & $0.73(0.52,1.03)$ & $0.69(0.49,0.98)^{*}$ \\
\hline Hong Kong (HK) & $0.91(0.66,1.26)$ & $0.73(0.54,0.97)^{*}$ \\
\hline Cuernavaca (MX) & $1.21(0.94,1.57)$ & $1.32(1.02,1.70)^{*}$ \\
\hline North Shore (NZ) & $1.27(0.68,2.36)$ & $1.10(0.59,2.05)$ \\
\hline Waitakere (NZ) & $1.62(1.00,2.61)^{*}$ & $1.82(1.11,2.98)^{*}$ \\
\hline Wellington (NZ) & $2.44(0.81,7.42)$ & $2.13(0.70,6.47)$ \\
\hline Christchurch (NZ) & $1.41(0.95,2.09)$ & $1.52(0.99,2.30)$ \\
\hline Pamplona (ES) & $0.87(0.64,1.17)$ & $0.64(0.48,0.85)^{* *}$ \\
\hline Stoke-on-Trent (UK) & $0.85(0.69,1.05)$ & $0.87(0.66,1.15)$ \\
\hline Seattle (US) & $0.75(0.42,1.34)$ & $0.66(0.37,1.17)$ \\
\hline Baltimore (US) & $0.88(0.49,1.58)$ & $0.81(0.45,1.45)$ \\
\hline
\end{tabular}

$95 \% \mathrm{Cl}=95 \%$ confidence interval; exp.(b) exponential function of regression coefficient; exp. $(95 \% \mathrm{Cl})=$ exponential function of confidence interval. Generalized additive mixed model (GAMM) with Gamma variance and logarithmic link functions, for which exp.(b) is interpreted as the proportional increase in PA associated with a 1 unit increase in the predictor. GAMMs adjusted for working status, marital status, administrative-unit-level socio-economic status and walkability

* $p$-value ranging from $\leq .05$ to $>.01$; ** $p$-value ranging from $\leq 01$ to $>.001 ; * * * 0.001$

The finding that females consistently undertook less transport and leisure-time PA, with few exceptions by city, replicates one of the most common findings in the international PA literature [7, 12, 14, 37]. The generalizability of this pattern across PA domains and across geographies is of particular concern because of the implications for increased NCD risk in the female half of the world population. The sex differences were most pronounced and most consistent at the highest levels ( $\geq 150 \mathrm{~min} /$ week) of transport and leisure-time PA. There were some differences by city, usually reflecting a lack of significant differences by sex in some cities, but this could be partly explained by modest sample sizes. An encouraging finding was that females were more likely than males to report $\geq 10 \mathrm{~min} /$ week of leisure-time PA in Ghent (BE) and Aarhus (DK), which could reflect cultural differences that should be studied in more depth. Present findings bring new urgency to the often-stated need for improved targeting of PA interventions for females [7, 37].

\section{Strengths and limitations}

Socio-demographic correlates are widely studied, but the present study added to the literature by providing estimates of domain-specific PA correlates across diverse countries. We examined both linear and curvilinear associations with binary and continuous leisure-time and transport PA outcomes, yielding important new information on the shape of associations of age with PA. Limitations of the study included the cross-sectional design, small number of countries with no low-income countries, samples that were not designed to be representative of populations, and the fact that sample sizes differed across countries resulting in varying power to detect city-specific associations. Although IPAQ has the strength of providing domain-specific PA estimates, it is documented that PA is over-reported with IPAQ [38]. Among other limitations are self-reported PA, analysis of only two PA domains, reporting of bouts of at least $10 \mathrm{~min}$, and inability to examine total reported PA. The association between educational attainment and physical activity might have been clarified if household income data were available.

\section{Conclusions}

The present study examined socio-demographic correlates of PA for transport and leisure-time purposes, and international variations were documented by age, education, and sex. These results can be used to inform 
Table 5 City-specific associations of sex (reference category: male) with physical activity (PA) outcomes

\begin{tabular}{|c|c|c|c|}
\hline \multirow[t]{4}{*}{ City } & Non-zero min/week of transport PA ${ }^{\mathrm{b}}$ & $\geq 10 \mathrm{~min} /$ week of leisure-time $P A^{a}$ & Non-zero min/week of leisure-time $\mathrm{PA}^{\mathrm{b}}$ \\
\hline & $F(17,10,125)=3.86^{* * *}$ & $F(17,13,192)=3.04^{* * *}$ & $F(17,9384)=4.36^{* * *}$ \\
\hline & Sex: Female & Sex: Female & Sex: Female \\
\hline & $e^{b}\left(e^{95 \% c l}\right)$ & $e^{b}\left(e^{95 \% c l}\right)$ & $e^{b}\left(e^{95 \% c l}\right)$ \\
\hline Adelaide (AU) & $0.86(0.77,0.96)^{* *}$ & $0.76(0.62,0.92)^{* *}$ & $0.89(0.81,0.98)^{*}$ \\
\hline Ghent (BE) & $0.98(0.84,1.16)$ & $1.38(1.05,1.80)^{*}$ & $0.89(0.78,1.01)$ \\
\hline Curitiba (BR) & $0.69(0.57,0.84)^{* * *}$ & $1.41(0.98,2.03)$ & $0.98(0.81,1.19)$ \\
\hline Bogota (CO) & $0.77(0.65,0.91)^{* *}$ & $0.61(0.37,0.99)^{*}$ & $0.61(0.52,0.72)$ \\
\hline Olomouc (CZ) & $1.09(0.79,1.52)$ & $1.42(0.71,2.86)$ & $1.07(0.81,1.42)$ \\
\hline Hradec Králové (CZ) & $0.93(0.62,1.40)$ & $0.83(0.29,2.35)$ & $1.09(0.76,1.56)$ \\
\hline Aarhus (DK) & $0.99(0.80,1.21)$ & $1.69(1.06,2.71)^{*}$ & $0.99(0.84,1.17)$ \\
\hline Hong Kong (HK) & $1.08(0.82,1.43)$ & $0.81(0.48,1.39)$ & $0.95(0.74,1.21)$ \\
\hline Cuernavaca (MX) & $0.62(0.51,0.75)^{* * *}$ & $1.22(0.73,2.02)$ & $0.83(0.67,1.03)$ \\
\hline North Shore (NZ) & $0.82(0.62,1.07)$ & $1.43(0.97,2.11)$ & $0.88(0.71,1.10)$ \\
\hline Waitakere (NS) & $0.83(0.64,1.09)$ & $1.15(0.79,1.66)$ & $0.83(0.68,1.01)$ \\
\hline Wellington (NZ) & $0.97(0.77,1.21)$ & $0.96(0.57,1.60)$ & $0.99(0.82,1.19)$ \\
\hline Christchurch (NZ) & $0.76(0.58 .1 .00)$ & $1.23(0.85,1.79)$ & $0.93(0.75,1.16)$ \\
\hline Pamplona (ES) & $0.92(0.78,1.09)$ & $1.04(0.68,1.60)$ & $0.76(0.66,0.87)^{* * *}$ \\
\hline Stoke-on-Trent (UK) & $1.08(0.89,1.32)$ & $1.06(0.80,1.42)$ & $0.81(0.68,0.97)^{*}$ \\
\hline Seattle (US) & $0.85(0.73,0.99)^{*}$ & $0.93(0.73,1.19)$ & $0.87(0.77,0.98)^{*}$ \\
\hline Baltimore (US) & $1.10(0.84,1.22)$ & $0.85(0.63,1.13)$ & $0.99(0.85,1.15)$ \\
\hline
\end{tabular}

$95 \% \mathrm{Cl}=95 \%$ confidence interval; exp.(b) exponential function of regression coefficient; exp. $(95 \% \mathrm{Cl})=$ exponential function of confidence interval

${ }^{a}$ Generalized additive mixed model (GAMM) with binomial variance and logit link functions, for which exp.(b) is interpreted as odds ratio

${ }^{b}$ GAMM with Gamma variance and logarithmic link functions, for which exp.(b) is interpreted as the proportional increase in PA associated with a 1 unit increase

in the predictor. All models adjusted for working status, marital status, administrative-unit-level socio-economic status and walkability

${ }^{*} p$-value ranging from $\leq .05$ to $>.01 ;{ }^{* *} p$-value ranging from $\leq 01$ to $>.001 ;{ }^{* * *} p \leq .001$

Table 6 Summary table of results: Main effects are shown for all socio-demographic factors by physical activity variables combinations. City-specific effects are shown when there were significant demographic by city interactions

\begin{tabular}{|c|c|c|c|c|c|c|}
\hline & $\geq 10 \mathrm{~min} /$ week of transport PA & $\begin{array}{l}\geq 150 \mathrm{~min} / \text { week } \\
\text { of transport PA }\end{array}$ & $\begin{array}{l}\text { Non-zero transport } \\
\text { PA min/week }\end{array}$ & $\begin{array}{l}\geq 10 \mathrm{~min} / \text { week } \\
\text { of leisure PA }\end{array}$ & $\begin{array}{l}\geq 150 \mathrm{~min} / \text { week } \\
\text { of leisure PA }\end{array}$ & $\begin{array}{l}\text { Non-zero } \\
\text { leisure PA } \\
\text { min/week }\end{array}$ \\
\hline Age & $\begin{array}{l}{[-]^{* * *}} \\
{[-] \text { Adelaide, Ghent, Curitiba, }} \\
\text { North Shore, Waitakere, } \\
\text { Christchurch, Stoke-on-Trent, } \\
\text { Seattle, Baltimore } \\
\text { [+] Cuernavaca, Pamplona }\end{array}$ & $\begin{array}{l}\text { X } \\
{[-] \text { Wellington }} \\
\text { [+] Hong Kong, } \\
\text { Pamplona }\end{array}$ & $\begin{array}{l}{[+]^{* *}} \\
{[+] \text { Ghent, }} \\
\text { Olomouc, Aarhus, } \\
\text { Pamplona }\end{array}$ & $\begin{array}{l}\text { X } \\
\text { [-] Bogota, Olomouc, Hradec } \\
\text { Králové, Aarhus, Cuernavaca, } \\
\text { Wellington, Seattle, Baltimore } \\
\text { [+] Pamplona }\end{array}$ & $x$ & $x$ \\
\hline $\begin{array}{l}\text { High school or } \\
\text { some college } \\
\text { (reference: < high } \\
\text { school graduate) }\end{array}$ & $x$ & $x$ & $x$ & {$[+]^{* * *}$} & {$[+]^{* * *}$} & $\begin{array}{l}\text { X } \\
{[+] \text { Waitakere }}\end{array}$ \\
\hline $\begin{array}{l}\text { College graduate } \\
\text { (reference: < high } \\
\text { school graduate) }\end{array}$ & $x$ & $x$ & {$[-]^{* *}$} & {$[+]^{* * *}$} & {$[+]^{* * *}$} & $\begin{array}{l}\text { X } \\
\text { [-] Aarhus, } \\
\text { Hong Kong, } \\
\text { Pamplona } \\
\text { [+] Bogota, } \\
\text { Cuernavaca, } \\
\text { Waitakere }\end{array}$ \\
\hline $\begin{array}{l}\text { Female sex } \\
\text { (reference: male) }\end{array}$ & $x$ & {$[-]^{* *}$} & $\begin{array}{l}{[-]^{* * *}} \\
{[-] \text { Adelaide, }} \\
\text { Curitiba, Bogota, } \\
\text { Cuernavaca, } \\
\text { Seattle }\end{array}$ & $\begin{array}{l}{[-]^{* *}} \\
{[-] \text { Adelaide, Bogota }} \\
{[+] \text { Ghent, Aarhus }}\end{array}$ & {$[-]^{* * *}$} & $\begin{array}{l}{[-]^{* * *}} \\
{[-] \text { Adelaide, }} \\
\text { Pamplona, } \\
\text { Stoke-on- } \\
\text { Trent, Seattle }\end{array}$ \\
\hline
\end{tabular}


targeting of interventions to subgroups at high risk for physical inactivity. A key finding was the generalizability of lower PA of females across leisure and transport domains and country. Tailoring PA interventions to the needs and interests of women should be a higher global public health priority. Education was primarily related positively to leisure-time PA, so interventions targeting this domain should be tailored to the needs of groups with lower education, and greater investment in interventions delivered to communities with low education are likely to be needed. Previous studies emphasized linear declines in PA with age, but present findings documented consistent curvilinear associations with leisuretime PA. This novel finding should be further investigated to determine how consistent it is using such nonlinear analyses.

\section{Acknowledgements}

Not applicable.

\section{Authors' contributions}

JM designed the study, collected data, secured funding, drafted and conceptualized the manuscript. EC designed the study, secured funding, drafted and conceptualized parts of the manuscript, analyzed and interpreted data. RR secured funding, collected data, drafted and conceptualized parts of the manuscript. TLC designed the study, coordinated international data, collected data, secured funding, interpreted data, edited. KLC designed the study, coordinated international data, collected data, secured funding, edited. MA coordinated international data, edited. GS secured funding, collected data, edited. OLS secured funding, collected data, edited. LBC secured funding, collected data, edited. RD secured funding, collected data, edited. DS collected data, edited. AAH collected data, edited. RO-G secured funding, collected data, edited. Duncan Macfarlane secured funding, collected data, edited. IDB designed the study, coordinated international data, collected data, secured funding, edited. NO designed the study, coordinated international data, collected data, secured funding, analyzed and interpreted data, edited. DVD collected data, edited: data collection, edited. JFS designed the study, coordinated international data, secured funding, interpreted data, edited. All authors read and approved the final manuscript.

\section{Funding}

Data collection in Hong Kong was supported by the grants (\#HKU740907H and \#747807H) and the HKU URC Strategic Research Theme (Public Health). US data collection and Coordinating Center processing was supported by the following NIH grant: R01 CA127296 (NCI). The study conducted in Bogota was funded by Colciencias grant 519 2010, Fogarty and CeiBA (Center in Complex-Systems, Basic and Applied Research at the Universidad de los Andes). Ester Cerin is supported by an Australian Research Council Future Fellowship (FT3 \#140100085). The contributions of Neville Owen were supported by a NHMRC Program Grant (\#569940), a NHMRC Senior Principal Research Fellowship (\#1003960), and by the Victorian Government's Operational Infrastructure Support Program. The Danish study was partly funded by the Municipality of Aarhus. Data collection in the Czech Republic was supported by the grant of Ministry of Education, Youths and Sports (\# MSM 6198959221). Data collection in New Zealand was supported by the Health Research Council of New Zealand grant \# 07/356. Data collection in Mexico was supported by the CDC Foundation which received an unrestricted training grant from The Coca-Cola Company.

\section{Availability of data and materials}

As the consent forms indicated that the data would be only accessible to the team of investigators, the data are confidential. De-identified data are however available from the authors upon reasonable request and with permission of national study coordinators.

\section{Ethics approval and consent to participate}

Each country obtained ethical approval from their local institutional review boards, and all participants provided informed consent.

\section{Consent for publication}

Not applicable.

\section{Competing interests}

The authors declare that they have no competing interests.

\section{Author details}

${ }^{1}$ Institute of Active Lifestyle, Faculty of Physical Culture, Palacký University, Olomouc, Czech Republic. ${ }^{2}$ Mary Mackillop Institute for Health Research, Australian Catholic University, Melbourne, Victoria, Australia. ${ }^{3}$ School of Public Health, The University of Hong Kong, Pok Fu Lam, Hong Kong, China. ${ }^{4}$ Prevention Research Center, Brown School, Washington University in St. Louis, Saint Louis, MO, USA. ${ }^{5}$ Urban Management Graduate Program, Pontifical Catholic University of Parana, Curitiba, Brazil. ${ }^{6}$ Department of Family Medicine and Public Health, University of California San Diego, La Jolla, CA, USA. ${ }^{7}$ Global Institute of Sustainability, College of Health Solutions, Arizona State University, Phoenix, AZ, USA. ${ }^{8}$ Faculty of Health and Environmental Sciences, AUT University, Auckland, New Zealand. ' 5 School of Medicine, Universidad de los Andes, Bogotá, Colombia. ${ }^{10}$ Department of Sports Science and Clinical Biomechanics, University of Southern Denmark, Odense, Denmark. ${ }^{11}$ Health Research Unit, University of Canberra, Canberra, Australia.

${ }^{12}$ University Public of Navarra, Pamplona, Spain. ${ }^{13}$ Centre for Sports and Exercise, University of Hong Kong, Pok Fu Lam, Hong Kong. ${ }^{14}$ Health Technology Graduate Program, Pontifical Catholic University of Parana, Curitiba, Brazil. ${ }^{15}$ Department of Movement and Sport Sciences, Faculty of Medicine and Health Sciences, Ghent University, Gent, Belgium. ${ }^{16}$ Baker Heart and Diabetes Institute, Melbourne, Australia. ${ }^{17}$ Swinburne University of Technology, Melbourne, Australia. ${ }^{18}$ Research Foundation Flanders, Brussels, Belgium.

Received: 31 July 2019 Accepted: 28 November 2019

Published online: 03 December 2019

\section{References}

1. United Nations. Political declaration of the high-level meeting of the General Assembly on the prevention and control of non-communicable diseases [Internet]. New York (NY); 2011. Available from: http://phstwlp2. partners.org:2139/nmh/events/un_ncd_summit2011/political_declaration_ en.pdf

2. WHO. Global action plan for the prevention and control of noncommunicable diseases, 2013-2020. Geneva: World Health Organization; 2013.

3. WHO. Noncommunicable diseases progress monitor 2017. Geneva: World helath Organization; 2017

4. WHO. Factsheets on health-enhancing physical activity in the 28 European Union member states of the WHO European region. Copenhagen: WHO Regional Office for Europe; 2015. p. 27.

5. Kankeu H, Saksena P, Xu K, Evans DB. The financial burden from noncommunicable diseases in low- and middle-income countries: a literature review. Health Res Policy Syst. 2013;11:1-12.

6. Abegunde DO, Mathers CD, Adam T, Ortegon M, Strong K. The burden and costs of chronic diseases in low-income and middle-income countries. Lancet. 2007;370:1929-1938. Available from: http://www.scopus.com/ inward/record.url?eid=2-s2.0-36549007517\&partnerlD=tZOtx3y1, [cited 2014 Dec 10].

7. Guthold R, Stevens GA, Riley LM, Bull FC. Worldwide trends in insufficient physical activity from 2001 to 2016: a pooled analysis of 358 populationbased surveys with 1.9 million participants. Lancet Glob Health. 2018;6: e1077-86. https://doi.org/10.1016/\$2214-109X(18)30357-7 World Health Organization.

8. Dumith SC, Hallal PC, Reis RS, Kohl HW. Worldwide prevalence of physical inactivity and its association with human development index in 76 countries. Prev Med. 2011;53:24-8. https://doi.org/10.1016/j.ypmed.2011.02 017 Elsevier Inc

9. WHO. Noncommunicable diseases country profiles 2018 [Internet]. Public Health. Geneva: World Health Organization; 2018. Available from: https:// www.who.int/nmh/publications/ncd-profiles-2018/en/ 
10. WHO. Global status report on noncommunicable diseases 2014. Geneva: World Health Organization; 2014.

11. Bauman AE, Reis RS, Sallis JF, Wells JC, Loos RJF, Martin BW. Correlates of physical activity: why are some people physically active and others not? Lancet Phys Act Ser Work Gr. 2012;380:31-44 Available from: http://www. scopus.com/inward/record.url?eid=2-s2.0-84877017766\&partnerlD=tZOtx3y1.

12. Trost SG, Owen N, Bauman AE, Sallis JF, Brown W. Correlates of adults' participation in physical activity: review and update. Med Sci Sports Exerc. 2002;34:1996-2001.

13. Solomon E, Rees T, Ukoumunne OC, Metcalf B, Hillsdon M. Personal, social, and environmental correlates of physical activity in adults living in rural south-West England: a cross-sectional analysis. Int J Behav Nutr Phys Act. 2013;10:1-15

14. Bauman A, Bull F, Chey T, Craig CL, Ainsworth BE, Sallis JF, et al. The International Prevalence Study on Physical Activity: results from 20 countries. Int J Behav Nutr Phys Act. 2009;6:21 Available from: http://ijbnpa. biomedcentral.com/articles/10.1186/1479-5868-6-21.

15. Hallal PC, Andersen LB, Bull FC, Guthold R, Haskell W, Ekelund U, et al. Global physical activity levels: surveillance progress, pitfalls, and prospects. Lancet. 2012;380:247-57. https://doi.org/10.1016/S0140-6736(12)60646-1 Elsevier Ltd.

16. Werneck AO, Baldew S-S, Miranda JJ, Díaz Arnesto O, Stubbs B, Silva DR. Physical activity and sedentary behavior patterns and sociodemographic correlates in 116,982 adults from six South American countries: The South American physical activity and sedentary behavior network (SAPASEN). Int J Behav Nutr Phys Act. 2019;16:1-11.

17. Kerr J, Sallis JF, Owen N, De Bourdeaudhuij I, Cerin E, Sugiyama T, et al. Advancing science and policy through a coordinated international study of physical activity and built environments: IPEN adult methods. J Phys Act Health. 2013;10:581-601.

18. Frank LD, Sallis JF, Saelens BE, Leary L, Cain L, Conway TL, et al. The development of a walkability index: application to the neighborhood quality of life study. Br J Sports Med. 2010;44:924-33.

19. Craig $C L$, Marshall $A L$, Sjöström M, Bauman $A E$, Booth $M L$, Ainsworth $B E$, et al. International physical activity questionnaire: 12-country reliability and validity. Med Sci Sports Exerc. 2003;35:1381-95 Available from: http://www. scopus.com/inward/record.url?eid=2-s2.0-0042855872\&partnerlD=tZOtx3y1, [cited 2014 Jul 9].

20. Wood SN. Generalized additive models: an introduction with R. Boca Raton (FL). Boca Raton: Chapman and Hall; 2006.

21. Cerin E, Cain KL, Conway TL, Van Dyck D, Hinckson E, Schipperijn J, et al. Neighborhood environments and objectively measured physical activity in 11 countries. Med Sci Sports Exerc. 2014:46:2253-64.

22. Burnham KP, Anderson DR. Model selection and multimodel inference: a practical information-theoretic approach. 2nd. New York (NY): Springer; 2002.

23. R Core Development Team. R: a language and environment for statistical computing, 3.2.1. doc. free. Available internet http//www. r-project. org. Vienna: R Foundation for Statistical Computing; 2015.

24. Fox J, Weisberg S. An R companion to applied regression, second edition. Thousand Oaks: Sage Publication; 2011. [cited 2018 Apr 12]. Available from: https://socialsciences.mcmaster.ca/jfox/Books/Companion/

25. Warnes GR. Various R programming tools for model fitting. Frederick: SAICFrederick, Inc.; 2012. p. 20.

26. Beenackers MA, Kamphuis CBM, Giskes K, Brug J, Kunst AE, Burdorf A, et al. Socioeconomic inequalities in occupational, leisure-time, and transport related physical activity among European adults: a systematic review. Int J Behav Nutr Phys Act. 2012;9:116.

27. Wallmann-Sperlich B, Froboese I. Physical activity during work, transport and leisure in Germany - prevalence and socio-demographic. PLoS One. 2014;9: e112333.

28. Cerin E, Leslie E, Sugiyama T, Owen N. Associations of multiple physical activity domains with mental well-being. Ment Health Phys Act. 2009;2:5564. https://doi.org/10.1016/j.mhpa.2009.09.004 Elsevier Ltd.

29. Sahlqvist S, Goodman A, Cooper AR, Ogilvie D. Change in active travel and changes in recreational and total physical activity in adults: Iongitudinal findings from the iConnect study. Int J Behav Nutr Phys Act. 2013;10:14-6.

30. Christiansen LB, Cerin E, Badland H, Kerr J, Davey R, Troelsen J, et al. International comparisons of the associations between objective measures of the built environment and transport-related walking and cycling: IPEN adult study. J Transp Health. 2016;3:467-78.
31. Becerra JM, Reis RS, Frank LD, Ramirez-Marrero FA, Welle B, Arriaga Cordero E, et al. Transport and health: a look at three Latin American cities. Cad Saude Publica. 2013;29:654-66.

32. Lachapelle U, Frank LD, Sallis JF, Saelens BE, Conway TL. Active transportation by transit-dependent and choice riders and potential displacement of leisure physical activity. J Plan Educ Res. 2016;36:225-38.

33. Abate T. Stanford researchers find intriguing clues about obesity by counting steps via smartphones. Standford: Stanford News Serv; 2017 Available from: https://news.stanford.edu/press-releases/2017/07/10/ stanford-researc-via-smartphones/

34. Reis RS, Hino AAF, Parra DC, Hallal PC, Brownson RC. Bicycling and walking for transportation in three Brazilian cities. Am J Prev Med. 2013;44:e9-17 Available from: http://www.sciencedirect.com/science/article/pii/S07493 79712007994, [cited 2015 Nov 9].

35. Teunissen T, Sarmiento O, Zuidgeest M, Brussel M. Mapping equality in access: the case of Bogotá's sustainable transportation initiatives. Int J Sustain Transp. 2015;9:457-67. https://doi.org/10.1080/15568318.2013. 808388

36. Beenackers MA, Kamphuis CBM, Prins RG, Mackenbach JP, Burdorf A, Van Lenthe FJ. Urban form and psychosocial factors: do they interact for leisuretime walking? Med Sci Sports Exerc. 2014;46:293-301.

37. WHO. Global action plan on physical activity 2018-2030: more active people for a healthier world 2018.

38. Bauman A, Ainsworth BE, Bull F, Craig CL, Hagstromer M, Sallis JF, et al. Progress and pitfalls in the use of the international physical activity questionnaire (IPAQ) for adult physical activity surveillance. J Phys Act Health. 2009;6:S5-8.

\section{Publisher's Note}

Springer Nature remains neutral with regard to jurisdictional claims in published maps and institutional affiliations.

\section{Ready to submit your research? Choose BMC and benefit from:}

- fast, convenient online submission

- thorough peer review by experienced researchers in your field

- rapid publication on acceptance

- support for research data, including large and complex data types

- gold Open Access which fosters wider collaboration and increased citations

- maximum visibility for your research: over $100 \mathrm{M}$ website views per year

At BMC, research is always in progress.

Learn more biomedcentral.com/submissions 